\title{
Conversion of Steroidal Vicinal Diols to the Corresponding Olefinic Compounds
}

\author{
Tsuyoshi WatanaBE ${ }^{* 1}$ and Suguru TAKatsuto*2 \\ *1 Tama Biochemical Co. Ltd. (2-7-1, Nishishinjuku, Shinjuku-ku, Tokyo 163-0704) \\ *2 Department of Chemistry, Joetsu University of Education \\ (1, Yamayashiki-machi, Joetsu-shi, Niigata-ken 943-8512)
}

\begin{abstract}
The wide applicability of two-step conversion of a vicinal diol group to carbon-carbon double bond developed by Corey and Winter was examined for various steroids with vicinal diol(s). By refluxing with triethyl phosphite, cyclic thionocarbonates derived from the vicinal diol steroids were converted to the corresponding olefinic steroids in high yields. Using this two-step conversion as a key step, brassinosteroid-related compounds, $(22 R, 23 R, 24 S)$ - and $(22 S, 23 S, 24 S)-2 \alpha, 3 \alpha, 22,23$-diepoxy- $B$ homo-7-oxa- $5 \alpha$-stigmastan-6-ones produced more efficiently than reported to date.
\end{abstract}

Key words : steroid, vicinal diol, thionocarbonate, triethyl phosphite, brassinosteroid

\section{Introduction}

Among the reactions to convert vicinal diol group to carbon-carbon double bond ${ }^{1)}$, a two-step reaction developed by Corey and Winter seems to be useful to many types of vicinal diol compounds, because the elimination of cyclic thionocarbonate is syn type and olefinic product is sterically controlled ${ }^{2,3)}$. However, the two step conversion has not been used widely so far. In the fields of steroids, we have recently applied the reaction to the conversion of $2 \alpha, 3 \alpha$-diol to $\Delta^{2}$-steroidal compound and we have synthesized stereoisomers of a phytohormone brassinolide ${ }^{4}$.

By epoxidation and lactonization of 2,22-dien-6one 1 with $m$-chloroperbenzoic acid or molecular oxygen and aldehyde, Brosa and Miro have reported the synthesis of two brassinosteroidrelated diepoxylactones 2 and 3 , which showed an interesting plant growth promoting activity in the rice lamina inclination test ${ }^{5)}$. However, their synthesis is not suited for obtaining enough amount for more detailed biological evaluation, because of the extremely low (3.4 and $2.3 \%$ ) yields of 2 and 3 . We have examined the wide applicability of the two-step reaction to more several kinds of steroidal vicinal diol compounds.

Corresponding author : Suguru TAKATSUTO

E-mail : takatuto@juen.ac.jp
Further, we have examined a more efficient synthesis of the diepoxylactones 2 and 3, using this reaction as a key step. In this paper, we wish to report these results.

\section{Experimental}

\section{$2 \cdot 1$ Analytical Methods}

Melting points were determined under a hotstage microscope (Yanaco micro melting point apparatus) and not corrected. ${ }^{1} \mathrm{H}(300 \mathrm{MHz})$ - and ${ }^{13} \mathrm{C}(75 \mathrm{MHz})-\mathrm{NMR}$ spectra were recorded on a Varian XL-VXR 300 spectrometer in a deuteriochloroform solution with tetramethylsilane as an internal standard. HR-FAB-MS were recorded on a JEOL HX-110 mass spectrometer. Silica gel (Merck, Kieselgel 60, 70 230 mesh) was used for column chromatography. Reactions were monitored by TLC on silica gel plate (Merck, Kieselgel $60 \mathrm{~F}_{254}, 0.25 \mathrm{~mm}$ thickness). Spots were visualized with $10 \% \mathrm{H}_{2} \mathrm{SO}_{4}$, followed by heating. All purified

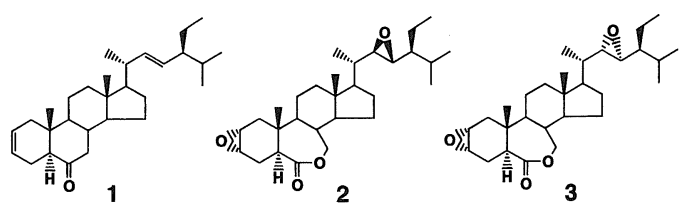

Fig. 1 Structures of $(22 E, 24 S)$-5 $\alpha$-Stigmasta-2,22-dien6-one $1,(22 R, 23 R, 24 S)$ - and $(22 S, 23 S, 24 S)-2 \alpha$, $3 \alpha, 22,23$-diepoxy- $B$-homo-7-oxa- $5 \alpha$-stigmastan6-ones 2 and 3. 
compounds showed a single spot by TLC analysis.

\section{$2 \cdot 2$ Steroids}

$(22 S, 23 S, 24 S)$-22,23-Dihydroxy-5 $\alpha$-stigmast-2en-6-one $\mathbf{9}, \quad(22 S, 23 S, 24 S)-2 \alpha, 3 \alpha, 22,23$-tetrahydroxy-5 $\alpha$-stigmastan-6-one 11 , and $(22 S, 23 S, 24 S)$ $2 \alpha, 3 \alpha, 22,23$-tetrahydroxy- $B$-homo-7-oxa- $5 \alpha$-stigmastan-6-one 13 were prepared according to the reported methods ${ }^{6,7)}$. $(22 E, 24 S)-2 \beta, 3 \beta$-Dihydroxy$5 \alpha$-stigmast-22-en-6-one 4 and $(22 E, 24 S)-2 \beta, 3 \beta$ dihydroxy-5 $\beta$-stigmast-22-en-6-one 6 were prepared by saponification of a known $(22 E, 24 S)$ $2 \beta, 3 \beta$ - dipropionyloxy $-5 \alpha$-stigmast -22 - en -6 - one ${ }^{8}$ followed by chromatographic separation and their structures were confirmed by spectral data and also by the reported data" .

2.3 Typical Procedure for Preparation of Thionocarbonates with Thiophosgene

A solution of thiophosgene $(30 \mu \mathrm{L}, 0.39 \mathrm{mmol})$ in dichloromethane $\left(\mathrm{CH}_{2} \mathrm{Cl}_{2}\right)(3 \mathrm{~mL})$ was added dropwise to a solution of $(22 E, 24 S)-2 \beta, 3 \beta$-dihydroxy- $5 \alpha$-stigmast-22-en-6-one $4(119.7 \mathrm{mg}, 0.270$ $\mathrm{mmol})$ and 4-dimethylaminopyridine $(150 \mathrm{mg})$ in $\mathrm{CH}_{2} \mathrm{Cl}_{2}(10 \mathrm{~mL})$ at $0^{\circ} \mathrm{C}$ and the mixture was stirred at $0^{\circ} \mathrm{C}$ for $1 \mathrm{~h}$. The reaction was quenched by addition of water and the mixture was extracted with $\mathrm{CH}_{2} \mathrm{Cl}_{2}$. The organic phase was successively washed with $2 \mathrm{M} \mathrm{HCl}$, sat. $\mathrm{NaHCO}_{3}$ and brine, dried over anhydrous $\mathrm{MgSO}_{4}$, filtered, and concentrated in vacuo. A residue was applied to a column of silica gel $(1.0 \mathrm{~cm}$ i.d. $\times 10 \mathrm{~cm})$. Elution with hexane-ethyl acetate $(10: 1$, vol/vol) provided $(22 E, 24 S)-2 \beta, 3 \beta$-dihydroxy- $5 \alpha$-stigmast-22-en-6one 2,3-thionocarbonate 5 (130.6 mg, 99\%), mp $242 \sim 244^{\circ} \mathrm{C}$ (from hexane), ${ }^{1} \mathrm{H}-\mathrm{NMR} \delta: 0.69(3 \mathrm{H}$, s, $\left.18-\mathrm{H}_{3}\right), 0.79\left(3 \mathrm{H}, \mathrm{d}, J=6 \mathrm{~Hz}, 26-\mathrm{H}_{3}\right), 0.80(3 \mathrm{H}$, t, $\left.J=7 \mathrm{~Hz}, 29-\mathrm{H}_{3}\right), 0.84\left(3 \mathrm{H}, \mathrm{d}, J=6.5 \mathrm{~Hz}, 27-\mathrm{H}_{3}\right)$, $0.90\left(3 \mathrm{H}, \mathrm{s}, 19-\mathrm{H}_{3}\right), 1.02(3 \mathrm{H}, \mathrm{d}, J=6.5 \mathrm{~Hz}, 21-$ $\left.\mathrm{H}_{3}\right), 2.54(1 \mathrm{H}, \mathrm{d}, J=10 \mathrm{~Hz}, 5 \alpha-\mathrm{H}), 4.88(2 \mathrm{H}, \mathrm{m}$, $2 \alpha-\mathrm{H}$ and $3 \alpha-\mathrm{H}), 5.02(1 \mathrm{H}, \mathrm{dd}, J=15$ and $8.5 \mathrm{~Hz}$, $22-\mathrm{H})$, and $5.12(1 \mathrm{H}, \mathrm{dd}, J=15$ and $8 \mathrm{~Hz}, 23-\mathrm{H})$. ${ }^{13} \mathrm{C}-\mathrm{NMR} \delta: 12.2(\times 2), 14.2,19.0,21.0,21.1$, 21.2, 22.7, 24.0, 25.3, 28.6, 31.8, 37.0, 37.9, 39.1, $39.7,40.3,42.7,46.5,51.3,52.8,54.3,55.9,56.7$, 79.5, 80.1, 129.8, 137.7, 191.4, and 208.1. HRFAB-MS $m / z$ : Calcd. for $\mathrm{C}_{30} \mathrm{H}_{47} \mathrm{O}_{3} \mathrm{~S}\left([\mathrm{M}+\mathrm{H}]^{+}\right)$: 487.3246. Found : 487.3261.

$(22 E, 24 S)-2 \beta, 3 \beta$-Dihydroxy- $5 \beta$-stigmast-22-en6-one 2,3-thionocarbonate $7(99 \%, 749.3 \mathrm{mg}$ from $690 \mathrm{mg}$ of 6), $\mathrm{mp} 202 \sim 204^{\circ} \mathrm{C}$ (from hexane), ${ }^{1} \mathrm{H}$ NMR $\delta: 0.69\left(3 \mathrm{H}, \mathrm{s}, 18-\mathrm{H}_{3}\right), 0.79(3 \mathrm{H}, \mathrm{d}, J=6$
$\left.\mathrm{Hz}, 26-\mathrm{H}_{3}\right), 0.80\left(3 \mathrm{H}, \mathrm{t}, J=7 \mathrm{~Hz}, 29-\mathrm{H}_{3}\right), 0.84$ $\left(3 \mathrm{H}, \mathrm{d}, J=6.5 \mathrm{~Hz}, 27-\mathrm{H}_{3}\right), 1.00\left(3 \mathrm{H}, \mathrm{s}, 19-\mathrm{H}_{3}\right)$, $1.02\left(3 \mathrm{H}, \mathrm{d}, J=6 \mathrm{~Hz}, 21-\mathrm{H}_{3}\right), 2.34(1 \mathrm{H}, \mathrm{dd}, J=4$ and $12.5 \mathrm{~Hz}, 5 \beta-\mathrm{H}), 4.96(2 \mathrm{H}, \mathrm{m}, 2 \alpha-\mathrm{H}$ and $3 \alpha-\mathrm{H})$, $5.02(1 \mathrm{H}, \mathrm{dd}, J=15$ and $8.5 \mathrm{~Hz}, 22-\mathrm{H})$, and 5.12 $(1 \mathrm{H}, \mathrm{dd}, J=15$ and $8 \mathrm{~Hz}, 23-\mathrm{H}) \cdot{ }^{13} \mathrm{C}-\mathrm{NMR} \delta: 12.2$ ( $\times 2), 19.0,21.1,21.2,21.7,23.3,23.9,25.4,26.2$, 28.7, 31.8, 35.8, 36.2, 38.6, 39.3, 40.3, 42.6, 42.8, $43.2,51.2,52.6,55.9,56.8,78.2,78.6,129.9$, 137.7, 191.2, and 211.3. HR-FAB-MS $m / z$ : Calcd. for $\mathrm{C}_{30} \mathrm{H}_{47} \mathrm{O}_{3} \mathrm{~S}\left([\mathrm{M}+\mathrm{H}]^{+}\right)$: 487.3246. Found : 487.3239 .

(22S,23S,24S)-22,23-Dihydroxy-5 $\alpha$-stigmast-2en-6-one 22,23-thionocarbonate 10 (93\%, 543.2 $\mathrm{mg}$ from $535.4 \mathrm{mg}$ of 9 ), $\mathrm{mp} 238 \sim 240^{\circ} \mathrm{C}$ (from hexane), ${ }^{1} \mathrm{H}-\mathrm{NMR} \delta: 0.71\left(3 \mathrm{H}, \mathrm{s}, 18-\mathrm{H}_{3}\right), 0.73$ $\left(3 \mathrm{H}, \mathrm{s}, 19-\mathrm{H}_{3}\right), 0.96\left(3 \mathrm{H}, \mathrm{d}, J=6.5 \mathrm{~Hz}, 26-\mathrm{H}_{3}\right)$, $0.99\left(3 \mathrm{H}, \mathrm{d}, J=6.5 \mathrm{~Hz}, 27-\mathrm{H}_{3}\right), 1.00(3 \mathrm{H}, \mathrm{d}, J=6$ $\left.\mathrm{Hz}, 21-\mathrm{H}_{3}\right), 1.02\left(3 \mathrm{H}, \mathrm{t}, J=7 \mathrm{~Hz}, 29-\mathrm{H}_{3}\right), 2.36$ $(1 \mathrm{H}, \mathrm{dd}, J=12.5$ and $4 \mathrm{~Hz}, 5 \alpha-\mathrm{H}), 4.66(1 \mathrm{H}, \mathrm{m}$, 23-H), $4.72(1 \mathrm{H}, \mathrm{m}, 22-\mathrm{H})$, and 5.52-5.72 $(2 \mathrm{H}, \mathrm{m}$, 2-H and $3-\mathrm{H}) .{ }^{13} \mathrm{C}-\mathrm{NMR} \delta: 11.8,12.2,13.1,13.5$, $18.3,18.7,21.0,21.7,22.1,24.1,26.4,27.9,37.5$, $39.3,39.6,39.9,43.5,46.8,49.4,51.0,53.2,53.9$, $56.2,77.2,83.1,87.1,124.4,125.0,191.5$, and 211.3. HR-FAB-MS $\mathrm{m} / z$ : Calcd. for $\mathrm{C}_{30} \mathrm{H}_{47} \mathrm{O}_{3} \mathrm{~S}$ $\left([\mathrm{M}+\mathrm{H}]^{+}\right):$487.3246. Found : 487.3247.

$(22 S, 23 S, 24 S)-2 \alpha, 3 \alpha, 22,23-T e t r a h y d r o x y-5 \alpha-$ stigmastan-6-one 2,3- and 22,23-bisthionocarbonate $\mathbf{1 2}(91 \%, 165.5 \mathrm{mg}$ from $167.7 \mathrm{mg}$ of $\mathbf{1 1}), \mathrm{mp}$ $316 \sim 318^{\circ} \mathrm{C}$ (from hexane- $\mathrm{CH}_{2} \mathrm{Cl}_{2}$ ), ${ }^{1} \mathrm{H}-\mathrm{NMR} \delta$ : $0.72\left(6 \mathrm{H}, \mathrm{s} \times 2,18-\mathrm{H}_{3}\right.$ and $\left.19-\mathrm{H}_{3}\right), 0.98(3 \mathrm{H}, \mathrm{d}, J=$ $\left.6.5 \mathrm{~Hz}, 26-\mathrm{H}_{3}\right), 1.00\left(6 \mathrm{H}, \mathrm{d} \times 2, J=6.5 \mathrm{~Hz}, 21-\mathrm{H}_{3}\right.$ and $\left.27-\mathrm{H}_{3}\right), 1.10\left(3 \mathrm{H}, \mathrm{t}, J=7 \mathrm{~Hz}, 29-\mathrm{H}_{3}\right), 2.53$ $(1 \mathrm{H}, \mathrm{dd}, J=12.5$ and $4 \mathrm{~Hz}, 5 \alpha-\mathrm{H}), 4.64(1 \mathrm{H}, \mathrm{m}$, 23-H), $4.72(1 \mathrm{H}, \mathrm{m}, 22-\mathrm{H}), 4.90(1 \mathrm{H}, \mathrm{m}, 2 \beta-\mathrm{H})$, and $4.95(1 \mathrm{H}, \mathrm{m}, 3 \beta-\mathrm{H}) .{ }^{13} \mathrm{C}-\mathrm{NMR} \delta: 11.8,12.3$, $12.8,13.2,18.3,18.8,21.0,21.5,22.1,24.1,26.4$, $27.9,37.2,38.6,39.0,39.6,41.1,43.5,46.4,49.5$, 50.6, 51.0, 52.5, 56.0, 78.1, 79.7, 83.2, 87.0, 191.4, 191.5, and 208.6. HR-FAB-MS $m / z$ : Calcd. for $\mathrm{C}_{31} \mathrm{H}_{47} \mathrm{O}_{5} \mathrm{~S}_{2} \quad\left([\mathrm{M}+\mathrm{H}]^{+}\right):$563.2865. Found : 563.2856.

$(22 S, 23 S, 24 S)-2 \alpha, 3 \alpha, 22,23-T e t r a h y d r o x y-B-$ homo-7-oxa-5 $\alpha$-stigmastan-6-one 2,3 - and 22,23 bisthionocarbonate $14(69 \%, 523.5 \mathrm{mg}$ from 649.6 $\mathrm{mg}$ of 13 ), $\mathrm{mp} 148 \sim 150^{\circ} \mathrm{C}$ (from $\mathrm{MeOH}$ ), ${ }^{1} \mathrm{H}$ $\operatorname{NMR}(500 \mathrm{MHz}) \delta: 0.78\left(3 \mathrm{H}, \mathrm{s}, 18-\mathrm{H}_{3}\right), 0.97(3 \mathrm{H}$, d, $\left.J=6.9 \mathrm{~Hz}, 26-\mathrm{H}_{3}\right), 0.97\left(3 \mathrm{H}, \mathrm{s}, .19-\mathrm{H}_{3}\right), 0.99$ $\left(3 \mathrm{H}, \mathrm{d}, J=6.9 \mathrm{~Hz}, 27-\mathrm{H}_{3}\right), 1.01(3 \mathrm{H}, \mathrm{d}, J=7.4 \mathrm{~Hz}$, 
21- $\left.\mathrm{H}_{3}\right), 1.04\left(3 \mathrm{H}, \mathrm{t}, J=7.4 \mathrm{~Hz}, 29-\mathrm{H}_{3}\right), 2.56(1 \mathrm{H}$, $\mathrm{dd}, J=16.3$ and $4.4 \mathrm{~Hz}), 2.94(1 \mathrm{H}, \mathrm{dd}, J=12.4$ and $2.8 \mathrm{~Hz}, 5 \alpha-\mathrm{H}), 4.07(1 \mathrm{H}, \mathrm{dd}, J=12.8$ and $10.1 \mathrm{~Hz}$, $7 \beta-\mathrm{H}), 4.14(1 \mathrm{H}$, dd, $J=13.1$ and $2.1 \mathrm{~Hz}, 7 \alpha-\mathrm{H})$, $4.56(1 \mathrm{H}, \mathrm{dd}, J=4.2$ and $4.2 \mathrm{~Hz}, 23-\mathrm{H}), 4.71(1 \mathrm{H}$, $\mathrm{dd}, J=5.1$ and $5.1 \mathrm{~Hz}, 22-\mathrm{H}), 5.11(1 \mathrm{H}, \mathrm{m}, 2 \beta-\mathrm{H})$, and $5.20(1 \mathrm{H}, \mathrm{m}, 3 \beta-\mathrm{H})$. HR-FAB-MS $\mathrm{m} / z$ : Calcd. for $\mathrm{C}_{31} \mathrm{H}_{47} \mathrm{O}_{6} \mathrm{~S}_{2}\left([\mathrm{M}+\mathrm{H}]^{+}\right)$: 579.2814 . Found : 579.2811.

2.4 Preparation of Thionocarbonate with 1,1-Thiocarbonyldiimidazole

A mixture of a known $(22 S, 23 S, 24 S)-2 \alpha, 3 \alpha$, 22,23-tetrahydroxy- $B$-homo-7-oxa- $5 \alpha$-stigmastan6-one $13^{7)}(66.1 \mathrm{mg}, \quad 0.134 \mathrm{mmol}), \quad 1,1-$ thiocarbonyldiimidazole ${ }^{2)}$ (198.3 $\left.\mathrm{mg}, 1.11 \mathrm{mmol}\right)$, and dry toluene $(7 \mathrm{~mL})$ was heated at reflux temperature under argon atmosphere for $3 \mathrm{~h}$. The solvent was evaporated and the residue was applied to a column of silica gel $(2.0 \mathrm{~cm}$ i.d. $\times 20$ $\mathrm{cm})$. Elution with hexane-ethyl acetate $(3: 1$, $\mathrm{vol} / \mathrm{vol})$ afforded $(22 S, 23 S, 24 S)-2 \alpha, 3 \alpha, 22,23$-tetrahydroxy- $B$-homo-7-oxa- $5 \alpha$-stigmastan-6-one 2,3 and 22,23-bisthionocarbonate $14(70.9 \mathrm{mg}, 91 \%)$, which was identical with the above-mentioned authentic sample.

2.5 Typical Procedure for the Reaction of a Thionocarbonate with Triethyl Phosphite

$(22 E, 24 S)-2 \beta, 3 \beta$-Dihydroxy- $5 \alpha$-stigmast-22-en6-one 2,3-thionocarbonate 5 ( $18.6 \mathrm{mg}, 38.3 \mu \mathrm{mol})$ was treated with triethyl phosphite $(3 \mathrm{~mL})$ at reflux temperature under argon for $5 \mathrm{~h}$. The reaction mixture was cooled and then extracted with toluene. The organic phase was washed with brine, dried over anhydrous $\mathrm{MgSO}_{4}$, filtered, and concentrated in vacuo. The residue was applied to a column of silica gel $(1.0 \mathrm{~cm}$ i.d. $\times 5.0 \mathrm{~cm})$. Elution with toluene provided $(22 E, 24 S)-5 \alpha$ stigmasta-2,22-dien-6-one 1 (17.1 mg, 92\%), mp $117 \sim 118^{\circ} \mathrm{C}$ (from $\mathrm{MeOH}$ ) [lit. ${ }^{10)}$, mp $114 \sim 115^{\circ} \mathrm{C}$ $(\mathrm{MeOH})]$. Its spectral data were identical with those of an authentic sample ${ }^{10)}$.

In the same manner, $(22 E, 24 S)-2 \beta, 3 \beta$-dihydrox$\mathrm{y}$-5 $\beta$-stigmast-22-en-6-one 2,3 -thionocarbonate 7 $(22.6 \mathrm{mg}, 46.5 \mu \mathrm{mol})$ was converted to $(22 E, 24 S)$ $5 \beta$-stigmasta-2,22-dien-6-one 8 (20.8 mg, 99\%), $\mathrm{mp} 133 \sim 134^{\circ} \mathrm{C}$ (from $\mathrm{MeOH}$ ), ${ }^{1} \mathrm{H}-\mathrm{NMR} \delta: 0.68$ $\left(3 \mathrm{H}, \mathrm{s}, 18-\mathrm{H}_{3}\right), 0.79\left(3 \mathrm{H}, \mathrm{d}, J=6 \mathrm{~Hz}, 26-\mathrm{H}_{3}\right), 0.80$ $\left(3 \mathrm{H}, \mathrm{t}, J=7 \mathrm{~Hz}, 29-\mathrm{H}_{3}\right), 0.84(3 \mathrm{H}, \mathrm{d}, J=6.5 \mathrm{~Hz}$, $\left.27-\mathrm{H}_{3}\right), 0.89\left(3 \mathrm{H}, \mathrm{s}, 19-\mathrm{H}_{3}\right), 1.01(3 \mathrm{H}, \mathrm{d}, J=6.5$
$\left.\mathrm{Hz}, 21-\mathrm{H}_{3}\right), 5.02(1 \mathrm{H}, \mathrm{dd}, J=15$ and $8.5 \mathrm{~Hz}, 22-$ $\mathrm{H}), 5.14(1 \mathrm{H}, \mathrm{dd}, J=15$ and $8 \mathrm{~Hz}, 23-\mathrm{H})$, and 5.64 $(2 \mathrm{H}, \mathrm{m}, 2-\mathrm{H}$ and $3-\mathrm{H}) .{ }^{13} \mathrm{C}-\mathrm{NMR} \delta: 12.2,12.3$, $19.0,21.0,21.2,21.9,23.1,24.0,25.4,26.7,28.8$, $31.9,34.3,37.0,37.2,39.6,40.4(\times 2), 41.8,43.0$, 51.2, 56.0, 56.5, 57.0, 123.7, 124.2, 129.6, 138.0, and 215.1. HR-FAB-MS $m / z$ : Calcd. for $\mathrm{C}_{29} \mathrm{H}_{47} \mathrm{O}$ $\left([\mathrm{M}+\mathrm{H}]^{+}\right): 411.3640$. Found : 411.3625.

In the same manner, $(22 S, 23 S, 24 S)$-22,23-dihydroxy-5 $\alpha$-stigmast-2-en-6-one 22,23-thionocarbonate $10(479.9 \mathrm{mg}, 0.987 \mathrm{mmol})$ and $(22 S, 23 S, 24 S)$ $2 \alpha, 3 \alpha, 22,23$-tetrahydroxy- $5 \alpha$-stigmastan-6-one 2 , 3- and 22,23-bisthionocarbonate $12(23.6 \mathrm{mg}, 45.4$ $\mu \mathrm{mol})$ were respectively converted to $(22 E, 24 S)$ $5 \alpha$-stigmasta-2,22-dien-6-one 1 (382 and $17.0 \mathrm{mg}$, 94 and $91 \%$, respectively).

In the same manner, $(22 S, 23 S, 24 S)-2 \alpha, 3 \alpha$, 22,23-tetrahydroxy- $B$-homo-7-oxa- $5 \alpha$-stigmastan6-one 2,3- and 22,23-bisthionocarbonate 14 (162.8 $\mathrm{mg}, 0.281 \mathrm{mmol})$ was converted to $(22 E, 24 S)-B$ homo-7-oxa-5 $\alpha$-stigmasta-2,22-dien-6-one $(106.9 \mathrm{mg}, 89 \%), \mathrm{mp} 98 \sim 99^{\circ} \mathrm{C}$ (from $\mathrm{MeOH}$ ) [lit. $\left.{ }^{4)}, \mathrm{mp} 99 \sim 101^{\circ} \mathrm{C}(\mathrm{MeOH})\right]$. Its spectral data were identical with those of an authentic sample ${ }^{4)}$.

$2 \cdot 6$ Epimerization of $(22 E, 24 S)-5 \beta$-Stigmasta-2,22-dien-6-one 8

A mixture of $(22 E, 24 S)-5 \beta$-stigmasta-2,22-dien6-one $8(18.3 \mathrm{mg}, 45.0 \mu \mathrm{mol})$, pyridinium $p$ toluenesulfonate $(5 \mathrm{mg})$, and $N, N$-dimethylacetamide $(3 \mathrm{~mL})$ was heated at $150^{\circ} \mathrm{C}$ for $3 \mathrm{~h}$. The reaction mixture was cooled and extracted with ethyl acetate. The extract was washed successively with $2 \mathrm{M} \mathrm{HCl}$, sat. $\mathrm{NaHCO}_{3}$, and brine, dried over anhydrous $\mathrm{MgSO}_{4}$, filtered, and concentrated in vacuo. The residue was applied to a column of silica gel $(1.0 \mathrm{~cm}$ i.d. $\times 5.0 \mathrm{~cm})$. Elution with toluene afforded $(22 E, 24 S)$-5 $\alpha$-stigmasta-2,22dien-6-one 1 (17.7 mg, 97\%). Its spectral data were identical with those of an authentic sample ${ }^{10)}$.

$2 \cdot 7$ Epoxidation of $(22 E, 24 S)-B-H o m o-7-$ oxa-5 $\alpha$-stigmasta-2,22-dien-6-one 15

A solution of $(22 E, 24 S)$ - $B$-homo-7-oxa- $5 \alpha$-stigmasta-2,22-dien-6-one $15(61.4 \mathrm{mg}, 0.144 \mathrm{mmol})$ in $\mathrm{CH}_{2} \mathrm{Cl}_{2}(10 \mathrm{~mL})$ was treated with $m$-chloroperbenzoic acid $(250 \mathrm{mg})$ at $0^{\circ} \mathrm{C}$ to room temperature for $3 \mathrm{~h}$. A solution of $\mathrm{NaHSO}_{3}(0.5 \mathrm{~g})$ in water $(5 \mathrm{~mL})$ was added dropwise to the reaction mixture and the whole was stirred at $0^{\circ} \mathrm{C}$ for $1 \mathrm{~h}$ before extraction with $\mathrm{CH}_{2} \mathrm{Cl}_{2}$. The organic phase was washed with sat. $\mathrm{NaHCO}_{3}$ and brine, dried over 
anhydrous $\mathrm{MgSO}_{4}$, filtered, and concentrated in vacuo. The residue was applied to a column of silica gel $(2.0 \mathrm{~cm}$ i.d. $\times 25 \mathrm{~cm})$. Elution with $\mathrm{CH}_{2} \mathrm{Cl}_{2}$-acetone $(50: 1$, vol/vol) provided $(22 R$, $23 R, 24 S)$ - $2 \alpha, 3 \alpha, 22,23$-diepoxy- $B$-homo-7-oxa- $5 \alpha$ stigmastan-6-one $2(31.9 \mathrm{mg}, 48 \%): \mathrm{mp} 157 \sim$ $158^{\circ} \mathrm{C}$ (from $\mathrm{MeOH}$ ) [lit. ${ }^{5}$, $\mathrm{mp} 104 \sim 107^{\circ} \mathrm{C}$ (solvent was not specified)], $\mathrm{R}_{\mathrm{F}}=0.69\left(\mathrm{CH}_{2} \mathrm{Cl}_{2}\right.$-acetone, $20: 1$, vol/vol). Its spectral data were identical with the reported data ${ }^{5)}$.

Further elution with the same solvent gave $(22 S, 23 S, 24 S)-2 \alpha, 3 \alpha, 22,23$-diepoxy- $B$-homo-7oxa-5 $\alpha$-stigmastan-6-one $3(24.9 \mathrm{mg}, 38 \%): \mathrm{mp}$ $162 \sim 164^{\circ} \mathrm{C}$ (from acetone) [lit. ${ }^{5)}$, mp $159 \sim 163^{\circ} \mathrm{C}$ (solvent was not specified)], $\mathrm{R}_{\mathrm{F}}=0.65\left(\mathrm{CH}_{2} \mathrm{Cl}_{2}\right.$ acetone, $20: 1$, vol $/ \mathrm{vol}$ ). Its spectral data were identical with the reported data ${ }^{5)}$.

\section{Results and Discussion}

The two-step reaction developed by Corey and Winter was at first applied to steroids with $2 \beta, 3 \beta$ diol, in order to test the mildness of the reaction condition. $5 \alpha$-Steroidal $2 \beta, 3 \beta$-diol 4 was reacted with thiophosgene in dichloromethane in the presence of 4-dimethylaminopyridine to form a cyclic thionocarbonate $\mathbf{5}$. Treatment of $\mathbf{5}$ with triethyl phosphite under reflux provided, after chromatographic purification, the known 2,22dien-6-one $\mathbf{1}^{10)}$ in $91 \%$ yield from the $2 \beta, 3 \beta$-diol 4 . The same procedure was applied to the $5 \beta$ steroidal $2 \beta, 3 \beta$-diol 6. A high yield $(98 \%)$ of $5 \beta$ steroidal dienone 8 was attained with retention of the stereochemistry at the C-5 position. It should be noted that no epimerized product 1 was detected under the reaction condition. Epimerization at the $\mathrm{C}-5$ position of 8 was easily effected by treatment with pyridinium $p$-toluenesulfonate and the $5 \alpha$-isomer 1 was obtained in $97 \%$ yield. Thus, the mildness of the reaction was confirmed based on the production of the compound 8 , which is both acid- and base-labile.

The procedure was then applied to brassinosteroid-related compounds with a vicinal diol in the side chain. The cyclic thionocarbonates $\mathbf{1 0}$ and 12, derived from 22,23-diol compound 9 and $2 \alpha, 3 \alpha, 22,23$-tetraol compound $\mathbf{1 1}$, were respectively subjected to the two-step reaction and the known 2,22E-dien-6-one $\mathbf{1}^{10)}$ was obtained in 88 and $83 \%$ yields, respectively. It is thus confirmed that formation of carbon-carbon double bond is sterically controlled with syn-elimination. It has been reported that brassinosteroid-related compounds with an unnatural $(22 S, 23 S)$-vicinal diol in the side chain were produced as by-products ( $c a$. $40 \%$ ), even by employing osmium-catalyzed asymmetric dihydroxylation of the steroidal 22-ene compounds, such as the 2,22-dien-6-one 1 or its related compounds ${ }^{11}$. Thus, the present data show that the two-step reaction is useful for converting the unnatural stereoisomers to the 22-ene compounds, which, in turn, can be re-subjected to the osmium-catalyzed asymmetric dihydroxylation, eventually, increasing the overall yield of brassinosteroids with natural $(22 R, 23 R)$-configuration, such as 28 -homocastasterone and 28-homobrassinolide.

We next investigated an efficient synthesis of the diepoxylactones 2 and 3 using the above-mentioned conversion as a key step. The reported method has a drawback of extremely low yield of the diepoxylactones 2 and $3^{5}$. Both epoxidation and lactonization of the 2,22-dien-6-one 1 were carried out in one step and epoxidation proceeded faster than lactonization ${ }^{5)}$. This may be the reason for the low yield. Thus, we planned to carry out at first the lactonization and then the epoxidation at both the $A$-ring and the side chain. Previously, Mori et al. reported a short-step preparation of the steroid 13 from stigmasterol ${ }^{7}$. Thus, we now applied the two-step conversion to this steroid $\mathbf{1 3}$. Following the method by Mori et al. ${ }^{7)}$ and our isomerization reaction of $3 \alpha, 5$-cyclopropyl $5 \alpha$ steroidal 6-one to $\Delta^{2}-5 \alpha$-steroid ${ }^{10)}$, the steroid 13 was obtained in $24 \%$ yield by nine step reaction from a commercial stigmasterol. The steroid $\mathbf{1 3}$ was converted to the bisthionocarbonate 14 in $69 \%$ yield by treatment with thiophosgene. When the steroid 13 was reacted with 1,1-thiocarbonyldiimidazole ${ }^{2)}$, the same bisthionocarbonate $\mathbf{1 4}$ was obtained in $91 \%$ yield. The bisthionocarbonate $\mathbf{1 4}$ thus obtained was then treated with triethyl phosphite to give a known lactonic diene $15^{4)}$ in $89 \%$ yield. Epoxidation of $\mathbf{1 5}$ with $m$-chloroperbenzoic acid provided, after chromatographic separation, $(22 R, 23 R)$-diepoxylactone 2 and its $(22 S, 23 S)$-isomer 3 in 48 and $38 \%$ yields, respectively.

In summary, we have achieved in a high yield the two-step conversion of the several kinds of steroids with vicinal diol group(s) to the corre- 


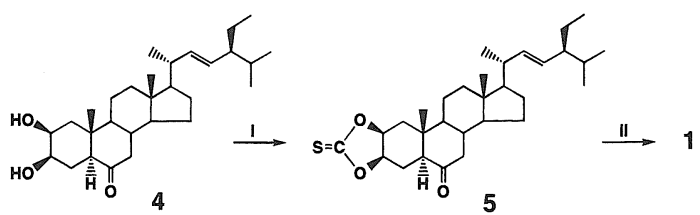

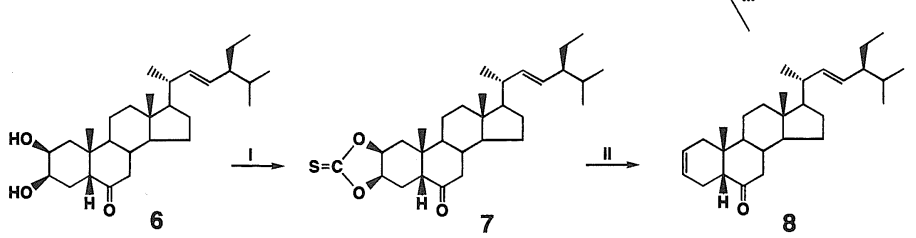

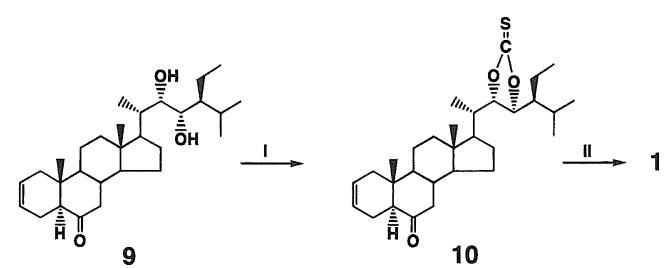

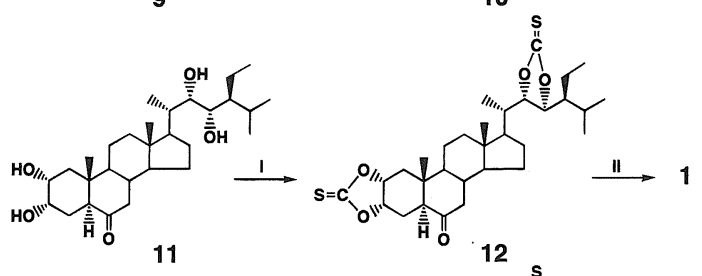

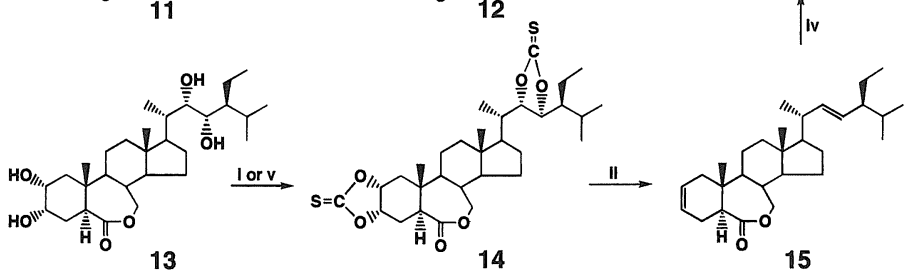

Scheme Reagent and conditions : $\mathrm{i}$, thiophosgene, DMAP, $\mathrm{CH}_{2} \mathrm{Cl}_{2}, 0^{\circ} \mathrm{C}, 1 \mathrm{~h}$; ii , triethyl phosphite, reflux, $5 \mathrm{~h}$; iii, PPTS, DMA, $150^{\circ} \mathrm{C}, 3 \mathrm{~h}$; iv , $m \mathrm{CPBA}, \mathrm{CH}_{2} \mathrm{Cl}_{2}, 0^{\circ} \mathrm{C}$, $1 \mathrm{~h} ; \mathrm{v}, 1,1$-thiocarbonyldiimidazole, toluene, reflux, $3 \mathrm{~h}$.

sponding olefinic compounds. Using the reaction as a key step, we have developed a more efficient route to the brassinosteroid-related diepoxylactones 2 and 3.

\section{Acknowledgement}

The authors thank Professor T. Yoshikawa and Dr. Y. Orihara of Kitasato University for the measurements of NMR and MS spectra.

(Received Aug. 27, 1999 ; Accepted Oct. 22, 1999)

\section{References}

1) J. March, "Advanced Organic Chemistry Reactions, Mechanisms, and Structure," 3rd ed., John Wiley \& Sons, Inc., New York, 1985, p.918.
2) E.J. Corey, R.A.E. Winter, J. Am. Chem. Soc., 85, 2677 (1963).

3) E.J. Corey, P.B. Hopkins, Tetrahedron Lett., 23, 1979 (1982).

4) T. Watanabe, S. Fujioka, T. Yokota, S. Takatsuto, J. Chem. Res., (S) : 744, (M) : 3301 (1998).

5) C. Brosa, X. Miro, Tetrahedron, 53, 11347 (1997).

6) M. Anastasia, P. Allevi, P. Ciuffreda, A. Oleotti, Steroids, 45, 561 (1985).

7) K. Mori, M. Sakakibara, Y. Ichikawa, H. Ueda, K. Okada, T. Umemura, G. Yabuta, S. Kuwahara, M. Kondo, Tetrahedron, 38, 2099 (1982).

8) S. Takatsuto, Y. Kamuro, T. Watanabe, T. Noguchi, H. Kuriyama, Proc. Plant Growth Regul. Soc. Am., 23, 15 (1996).

9) C. Brosa, S. Nusimovich, R. Peracaula, Steroids, 
59, 464 (1994).

10) T. Watanabe, H. Kuriyama, T. Furuse, K. Kobayashi, S. Takatsuto, Agric. Biol. Chem., 52,
2117 (1988).

11) C. Brosa, J.M. Capdevila, I. Zamora, Tetrahedron, 52, 2435 (1996). 


\title{
[ノート］ステロイド系ビシナルジオールの オレフィン化合物への変換
}

渡辺 剛*1 - 高津 戸 秀*2

*1 夕マ生化学 (广 163-0704 東京都新宿区西新宿 2-7-1)

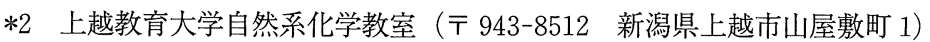

Corey および Winter によって開発されたヒジナルジオール基の炭素 - 炭素二重結合への 2 工程による変換反 応の適応性について，いくつかのタイプ別にビシナルジオールを有するステロイドについて検討した。ビシナル ジオールを有するステロイドから誘導された環状チオノカーボネートをトリエチルフォスファイトと加熱環流す ることにより, 対応するオレフィン系ステロイドへ高収率で変換された。この 2 工程変換反応を鍵反応に用いて, ブラシノステロイド関連化合物である $(22 R, 23 R, 24 S)$ - and $(22 S, 23 S, 24 S)-2 \alpha, 3 \alpha, 22,23$-diepoxy- $B^{-}$ homo-7-oxa-5 $\alpha$-stigmastan-6-ones を既に報告されている方法よりもより効率的に合成した。

（連絡者：高津戸 秀） Vol.49, No.2，163

(2000)

\section{[ノート］ガンピョウの種子中に含まれるカスタステロン およびステロールの同定}

\author{
高津戸秀 ・ 牧内華奈 \\ 上越教育大学自然系化学教室（广 943-8512 新潟県上越市山屋敷町 1)
}

カンピョウ (Lagenaria siceraria, ウリ科) の種子よりイネ葉身屈曲試験において活性な物質を抽出・分画し, 誘導体化後 GC-MS 分析を行ったところ，ブラシノステロイドの一種であるカスタステロンを同定した。また， 種子中のステロールについても GC-MS 分析を行った。標品との直接比較により，3種の $24-ア ル キ ル ー \Delta^{5}-ス$ テロールと 5 種の $24-$ アルキル - $\Delta^{7}$ - ステロールを同定した。

（連絡者：高津戸 秀） Vol.49, No.2, 169 （2000）

\section{[ノート] Stigmasta-5,25-dien-3 $\beta$-ol および \\ stigmasta-5,24 (25) -dien-3 $\beta$-ol の sitosterol からの簡便合成}

\author{
鳴海安久 ${ }^{* 1} \cdot$ 渡辺 剛*2・高津戸 秀*1 \\ *1 上越教育大学自然系化学教室 ( \\ *2 夕マ生化学（テ 163-0704 東京都新宿区西新宿 2-7-1)
}

Stigmasta-5,25-dien-3 $\beta$-ol の sitosterol からの合成について検討した。 Sitosterol 側鎖の methyl (trifluoromethyl) dioxirane による直接水酸化および 25 位水酸化化合物の phosphorus oxychloride による脱水反応 を鍵反応に用いた。Stigmasta-5,25-dien-3 $\beta$-ol および stigmasta-5,24(25)-dien-3 $\beta$-ol をitosterol から簡便に 合成した。それらは逆相カラムを用いる HPLCにより単離することができた。

（連絡者：高津戸 秀） Vol.49, No.2, 173

$(2000)$ 